\title{
Implementation of Multicultural Education Cooperative Learning to Develop Character, Nationalism and Religious
}

\author{
Moch. Yusuf Efendi ${ }^{1 *}$, Hsi-Nancy Lie ${ }^{1}$ \\ ${ }^{1}$ Department of Education and Human Potential Development (DEHPD), National Dong Hwa University, \\ Hualien, Taiwan \\ *yefendi934@yahoo.com
}

Received: November $20^{\text {th }}, 2019$

Revised: November $3^{\text {rd }}, 2020$

Accepted: November $28^{\text {th }}, 2020$

\begin{abstract}
Races, ethnic groups, nationalities, and religions are considered important for implementing multicultural education. the implementation of multicultural cooperative learning in an Islamic public primary school becomes a concern for this study. Therefore, this study aims to investigate the implementation of multicultural education in an Islamic Public School in Grobogan, Central Java. This study used descriptive qualitative, literature review, and a case study in an Islamic Public School. The findings of the study show that 1) multicultural education is a form of policy attention from the government and teachers about a variety of ethnicities and culture. multicultural education can be used as a strategic instrument to develop diverse ethnic and national cultures that can be a personal pride for the ethnic group. 2) Multicultural education is very suitable for a plural society such as Indonesia, which pays attention to the understanding of ethnic, religious, linguistic and ethnic differences, which requires new innovation democratic society. 3) Application of multicultural education in an integrated curriculum or integrated with other subjects. 4) The application of integrated multicultural education can use cooperative learning models. 5) The basis for efficient group formation is the formation of non-permanent groups with session agreements or face-to-face meeting agreements, which allow students to interact in turns with classmates. 6) Familiarization with the basis of the formation of varied groups in the cooperative learning model will develop an awareness that life now and later for students is no problem in adjustment.
\end{abstract}

Keywords: achievement; cooperative learning; multicultural; primary school; student; teacher.

\section{INTRODUCTION}

Indonesia is a country that has a multicultural diversity are considered of cultural, ethnic, and religious differences and languages, which are spread throughout Indonesia. so that local wisdom is needed in making appropriate, effective policies to respond to the development of local wisdom so that steps taken by policymakers do not slip and consequently endanger the nation's sustainability in the future (Zamroni, 2011).

Multicultural education is urgently needed by Indonesia to reduce the occurrence of horizontal conflicts 
between communities because cultural, ethnic, cultural and religious differences and language differences are an emphasis on learning to respect differences and are not considered to be causes of fragmentation (Zamroni, 2011). This can be done by selecting learning materials that contain nuances of multi-ethnic and multicultural tolerance in a shared frame and do not emphasize differences because of the ideological or group spirit. Normatively many religions and beliefs in multicultural nuances are expected to bring harmonious relations between ethnic groups, but in the implementation phase, there are still many gaps between expectations and realization because some people who think exclusively are still in a multicultural society (Cordasco, F., 1976).

In Indonesia, we find often conflicts occur involving ethnicity, religion, race, where there are fatalities such as events in Ambon, Poso, Sampit, Sambas, and various other regions, these differences can clash resulting in differences of opinion, lifestyle and cultural interests between ethnic with large tribes. Multiculturalism is the effort of the government and teachers and the community as a policy to unite each group to unite (to integrate) even though there is cultural diversity that is owned in order to fulfill the life of the nation, state and recognition of human rights today and encourage the emergence of a movement for recognition and equality cultural diversity and existence in society known as multiculturalism. All ethnic groups, religions, and races, can unite so that there is a process of "hybridization" so that each individual to respect differences in each culture (Zamroni, 2011).

Multiculturalism can develop well if it is consistent to become proficient and cultured in the next generation of education. Awareness of the importance of ethnic and religious differences, with education, can foster community respect for differences will develop if future generations are trained and made aware of the importance of respecting others and other cultures (Cordasco, F., 1976). Because, we need multicultural education to overcome various horizontal conflicts, such as ethnic, racial and religious diversity and vertical conflicts such as the level of education, economy, and social culture of the Indonesian state (Gardner, H., Csikszentmihalyi. M., \& Damon, W., 2009).

Technical issues in education require concepts of thought and development that require interdisciplinary participation, not just multicultural education, so multiculturalism education can be used as a philosophy of life, social reality, which can include other disciplines such as religion, social science, anthropology, sociology, etc (Gardner, $H_{\text {., }}$ Csikszentmihalyi. M., \& Damon, W., 2009). Multicultural education can also be used as a means to erode differences that can be the fruit of division, so we are interesting choose the topic in writing with the theme: "Implementation of Multicultural Education Cooperative Learning Developing Character, 
Nationalism and Religious Case Study in MIN 3 Grobogan Central Java Indonesia".

\section{METHODOLOGY}

Methodology used in this paper is literature review studies descriptive qualitative, and the case study. In essence, the literature review method is a method of collecting data that is done by taking the necessary data from the related literature. While qualitative descriptive research is a method of examining the status of a group of people, an object with the aim of making a description or painting systematically, factually and accurately of the facts investigated. This qualitative descriptive study aims to describe what is happening now. That is, this study describes, examines, analyzes and interprets the current conditions. In other words, qualitative descriptive research aims to obtain information on existing conditions.

This paper make reference to the fundamental interrelation between subject and method. The literature review methods can be obtained from various university libraries, website or other sources which support the idea. Then, the literatures review methods are clasify and analysis into each variable. This research helps us to choose which literature is best used for comparison of the literature (Sudardi, 2003). Classification is an effort to classify information obtained from the relevant literature and website in this case reduce existing data by arranging and classifying the data obtained into a particular pattern or a particular problem to facilitate the reading and discussion as needed. Analysis is the process of simplifying the word into a form that is easier to read and also easy to interpret by linking existing data sources and anaysis in accordance with the items studied in the study. Making conclusions as the final stages of data processing that is the conclusion of the data obtained after the analysis to obtain answers to the reader of what is presented on the background of the problem. In the case of MIN 3 Grobogan, "Implementation of Multicultural Education Cooperative Learning Developing Character, Nationalism and Religious Case Study in MIN 3 Grobogan Central Java Indonesia".

\section{LITERATURE REVIEW}

\section{a. Multiculturalism}

Multicultural comes from word multi (many) and word, culture (culture) and ism (flow/understanding). According to Suparlan (2002), the beginning of the word multiculturalism has a cultural meaning, namely culture as its function as a guide for human life. Multiculturalism as a point of view, which means various national cultural policies that emphasize the acceptance of ethnic, religious, linguistic and cultural characteristics, essential reality in human life. Multiculturalism is understood as cultural wisdom which is then manifested in political awareness (Azra, 2007).

Multiculturalism can be divided into five types, namely:1) Isolationist multiculturalism, namely groups of people, involved in interactions between 
individuals and groups, usually found in various cultural groups that run lives independently. As an example of this group, they accept diversity, but at the same time try to maintain their culture separately from other communities in general. like, in Madura and Kalimantan Indonesia. isolationist multiculturalism can be found in society. 2) Accommodative multiculturalism, namely homogeneous societies that have a dominant culture, make certain adjustments and accommodations for the cultural needs of minorities. Accommodating multicultural societies that formulate and apply laws, laws, and regulations that are culturally sensitive, and give freedom to minorities to defend and develop their culture, while minorities do not challenge the dominant culture. This "accommodative multiculturalism" model can be found in Britain, France, and several other European countries. 3) Autonomous multiculturalism, a plural society in which the main cultural groups try to realize equality with the dominant culture and want an autonomous life within a politically acceptable framework. Multicultural comes from multi (many) words and words, culture (culture) and ism (flow) / understanding). According to Suparlan (2002), the beginning of the word multiculturalism has a cultural meaning, namely culture as its function as a guide for human life. This last cultural group is to defend their way of life, which has the same rights as the dominant group; they challenge dominant cultural groups and try to create a society where all groups can live as equal partners (Glare. P.G.W., 2000). This multiculturalism is supported by Quebec groups in Canada, and Muslim immigrant groups in Europe, who demand to be able to implement sharia, education for their children in Islamic schools and so on. 4) interactive multiculturalism, pluralistic societies where cultural groups are less concerned with autonomous cultural life, but rather require the creation of a collective culture that reflects and confirms their distinctive perspectives. Dominant cultural groups naturally tend to reject these demands, and even try to force them to apply their dominant culture at the expense of the culture of minority groups (Glare. P.G.W., 2000). It is a minority group that challenges the dominant cultural group, both intellectually and politically, to create a climate conducive to the creation of a new egalitarian collective culture in a sincere way. This type of multiculturalism, for example, is fought by black communities in the United States, United Kingdom, and others. 5) Cosmopolitan multiculturalism, trying to eliminate "cultural boundaries" at the same time to create a society where each individual is no longer bound and committed to a particular culture and vice versa, freely involved in intercultural experiments and at the same time developing their cultural lives. respectively. Proponents of this type of multiculturalism are intellectuals and liberal groups, mostly diasporas who have a postmodernist tendency and view the whole culture as a resource that they 
can freely choose and take (Parekh, 2000).

\section{b. Multicultural Education}

There are many different opinions between multicultural and cultural education. first, we must know the terminology of different definitions of the goals of multicultural education itself, in order to get the truth in taking the opinion of these differences. second, many people are trapped in searching are cultural and multicultural formulations, multicultural education is inferred from it. so, it was concluded that multicultural education is an effort to teach various kinds of Indonesian culture, ranging from language, songs, clothing, etc. So, the basic concept of multicultural education itself becomes biased and does not achieve the expected goals.

According to Banks (2002), multicultural teaching strategies educational reform initially in the United States aims to eliminate or reduce racial, ethnic, and social group discrimination in the United States, and strive for everyone to get equal opportunities to get an education. Multicultural education is a set of explanations and beliefs that recognize and assess the importance of cultural and ethnic diversity in social experiences, personal identities, educational opportunities for individuals, groups, and country lifestyles (Tilaar, 2004). Multicultural education developed the idea of awareness of "interculturalism" after World War II. The ideas and "intercultural" awareness, besides being related to the development of international politics about human rights, independence from colonialism and racial discrimination, also increase plurality in western countries themselves due to increased migration from newly independent states in America, and Europe.

Multicultural teaching strategies recommended by UNESCO in October 1994 in Geneva, so that it became an idea of a global commitment that contained 3 main messages: First, education must develop the ability to recognize and accept values that exist in personal, gender, community and cultural diversity and develop the ability to communicate share and collaborate with others. Second, education must strengthen identity and encourage convergence of ideas and solutions that strengthen peace, goodwill, and solidarity between society and society. Third, education must improve the ability to resolve conflicts peacefully and without violence. thus, education must also enhance the development of peace in the minds of students so that they can build quality of tolerance, patience, willingness to share between different ethnic groups and religions (Geetz, 1973).

Multicultural education can be considered as a movement for renewal and a process to create an equal educational environment for all students. As a renewal movement and a process to create an equal educational environment for all students, because educational equality and service become the basis of multicultural education in facilitating 
educational experiences so that all students can realize their full potential and make them aware and become active people locally, national and global. Multicultural education must have the following principles:

a. Multicultural education has political practice that aims to achieve social justice for all citizens, regardless of ethnicity, religion, and ethnicity.

b. Multicultural education has two dimensions: learning (class) and institutional (school) and between the two cannot be separated, but instead must be addressed through overall cultural reform.

c. With a critical analysis of the education system to be able to carry out comprehensive reforms in education, multicultural education emphasizes comprehensive education reforms that can only be achieved through Multicultural teaching strategies.

d. Guaranteed to get the opportunity to achieve maximum performance with its ability for students is the goal of multicultural education to provide the same degree and fairness between students.

e. All students get the best education, regardless of their different backgrounds, can attend Multicultural Education (Banks, 2002).

The Multicultural Culture Society is the main concept in Multicultural Education. Many different definitions of culture such as that proposed by By (Geetz, 1973), there are many definitions of culture, but there is no single definition that all social scientists who wholeheartedly will accept. Culture is defined as a way of life of social groups in which some people create their environment (Banks, 2002: 52). Culture is the values, symbols, interpretations, and perspectives that distinguish one person from another in modern society, and not artifacts, material things, another tangible aspect of human society. Knowledge is not neutral or static, a culture based, perspective, dynamic, and changing (Banks, 2007: 15).

The reality of community diversity with all the differences in social, economic, political and cultural aspects is inevitable. The United States government once attempted to unify aspects of difference with the name of the "melting pot" policy, namely the unification of all cultures from various immigrants and minorities to merge into one of the dominant cultures. The failure of the melting pot finally developed a new policy, namely multicultural education. Multicultural Education Policy that was born from a deep awareness of the community who must respect and uphold the existence of various kinds of ethnicity, ethnicity, language, and culture of the community (Zamroni, 2011).

Awareness of multicultural characteristics needs to uphold the nature of tolerance and tolerance will give birth to a new awareness that collaboration with all differences is an absolute necessity. Modood further added that multicultural societies are not 
merely adjusting traditional culture to the needs of immigrants and minorities such as individual freedom within their groups, but Multicultural Communities are understood as individual and community equality in democracies that seek to adapt positively rather than damage, unity, and equality of community identity and national (Zamroni, 2008).

Multicultural society, where diversity is also clearly written on the symbol of the State of Pancasila namely Bhinneka Tunggal Ika. It is necessary for education to foster attitudes, awareness and social care and share with others regardless of their ethnicity, ethnicity, religion, class, group and so on. Humans as social beings already have social concerns, because humans need each other and cannot live alone.

Multicultural education was preceded by bad experiences experienced by the people of the United States, namely the suppression of dominant culture over minority cultures. The dominant culture is called (WMCA) group culture, namely white culture, male culture, Christian culture (Cristian), and culture coming from Western Europe (Anglo Saxon). The suppression of dominant culture over minority cultures, eventually developed in the socio-economic suppression. Minority residents find it difficult to find work, and there is a clear discriminatory policy. Multicultural education was born and developed in the United States. James Banks (1995) explained the birth of multicultural education as inseparable from the movement to obtain equality of rights that occurred in the 1960s with the following statement: "Multicultural Education grew out of the ferment of the civil rights movement of the 1960s". Furthermore, Banks and Banks (2001) reported that multicultural education was born in the United States as a movement to get equal education for women, groups, ethnicities, non-English language minority groups, low-income groups and special ability groups (Zamroni, 2011).

Multicultural Education is a comprehensive school reform process and is the basis of education for all students. This is a challenge to eliminate racism and all forms of discrimination in schools and society, and to accept pluralism, from the student and teacher community. Seven basic characteristics of multicultural education in this definition, namely: 1) multicultural education that is anti-racism, 2) multicultural education is the basis of education, 3) multicultural education is very important for all students, 4) multicultural education is a subject that can be absorbed in other lessons (pervasive), 5) multicultural education is education for social justice, 6) multicultural education is a process, and 7) multicultural education is a critical pedagogy. Furthermore, according to Banks (2007b), Multicultural Education consists of three main components, namely: 1) ideas or concepts, 2) educational reform movements and 3 ) processes (Nieto in Noel, 2000).

\section{c. Cooperative Learning}

Cooperative learning is a form of learning based on constructivism. Cooperative learning is a learning 
strategy with some students as members of small groups with different levels of ability. In completing their group assignments, each student must work together, helping each other to understand the subject matter.

In learning it is said to be incomplete if one member has not mastered the lesson material (Isjoni, 2011: 14). Slavin (2005: 10), Student Team Learning Method (MSTL) is a technique developed and examined by John Hopkins University. This method emphasizes the use of team goals and team success. Therefore, the assignments given to students are not doing something as a team but learning something as a team. Furthermore, Slavin put forward three concepts that characterize cooperative learning, namely:

a. Group appreciation, where group success is based on the appearance of individuals in creating interpersonal relationships, mutual support, help, and care for each other.

b. Individual responsibility depends on the individual learning of all members.

c. Equal opportunity to succeed, the scoring method used includes the value of progressive improvement in achievement obtained by previous students. Thus, students with low, medium and high achievements both have the opportunity to succeed.
The five elements Cooperative learning approach models must apply (Anita Lie, 2008), namely:

a. Positive interdependence is each member trying to obtain group success.

b. Individual responsibility is the first level, responsible for obtaining the success of each group member for the success of the group.

c. Face to face is each member must meet and discuss, conduct interactive activities to help students form cooperation that depends on all members.

d. Communication between members is the success of the group depending on the desire of members to listen to each other and their ability to present their opinions.

e. Group process evaluation is the improvement of more effective group activities through assessments that are very important and require student success. The implementation can be done after some time of cooperative learning, it does not have to be done every time there is group work.

The elements in cooperative learning according to Lungdren (1994), as quoted by Isjoni (2011: 16) as follows:

a. Students must have the view that they are the same boat.

b. Students must have the responsibility of other students in 
the group in learning the material at hand.

c. Students must be of the view that they have the same goal.

d. Students share assignments and responsibilities among their members.

e. Students are given an evaluation or award that will influence the group evaluation.

f. Students share leadership while they acquire cooperative skills while studying.

g. Each student will be asked individually to take responsibility for the material handled in a cooperative group.

Cooperative learning can be implemented by instilling basic elements of student learning effectively by implementing cooperative learning so that the application of cooperative learning in a sustainable manner can be used as a means for teachers to train and develop cognitive, affective and psychomotor aspects of students, as well as social skills for living in society.

The success of students in this learning also has an impact on the success of teachers in managing their classrooms (Isjoni, 2011: 102). So in this cooperative learning, students learn how to work together in groups, lead one another, take responsibility for equality in learning that is the same fate and responsibility, create interpersonal relationships, support each other, help each other, and care for each other in achieving goals namely success in mastering learning material. Cooperative
Learning Practices in Banks' Multicultural Education (2002: 29), suggests educators use several approaches, to integrate cultural content into the school curriculum. These approaches, namely:

a. Contribution approach, where content about ethnic and cultural groups is limited especially for holidays and cultural celebrations.

b. An additive approach, in this approach, cultural contents, concepts, and themes are added to the curriculum without changing the basic structure, goals, and characteristics. An additive approach is often done by adding books, units, or courses to the curriculum without changing the framework.

c. The fundamental transformation approach is different from the contribution and additive approach. The important aim of this transformation approach is to teach students to think critically and develop skills to formulate, document, and justify conclusions and generalizations.

Policy Makers gives the decision to take a transformative social action approach extending the curriculum by enabling students to pursue projects and activities that enable them, to be able to make personal, social, and related actions with the concepts, problems and problems they have learned. While Zamroni (2011) argues that cultural education as a process of awareness provides the direction in which the transformation of educational practices 
must lead. The position of an appropriate educational system and practice to achieve optimal performance is education which: 1) emphasizes equality and fairness, 2) the learning process is kept away from the nature of bias and stereotypes, 3) the learning process must lead to the development of cultural abilities within students. It was further stated that cultural competence can be shaped by four factors: a) mastery of knowledge, b) critical strength or critical thinking, c) ability to develop knowledge and d) ability of practice.

These factors continue to develop, interrelated and provide feedback with dynamic adjustments to existing conditions and situations, and ultimately result in cultural competence. To develop multicultural education, schools must also have a democratic culture. School culture plays an important and strategic role in the continuity of learning. A positive culture will have two impacts, namely to students and to educators.

In principle, there are three alternatives in developing school culture, namely: First is the "hidden curriculum" culture change can be through habituation and acculturation by example. The lower the level of education the more important the teacher's example. The second is hardaction where habituation and acculturation through 3-SA are: being forced, forced and ordinary (Zamroni, 2011).

Multicultural learning is expected to provide stimulus to students as an effort to prevent conflict. Living together with various cultures (multicultural) is an obligation as Indonesia nation which indeed consists of various ethnic backgrounds, religions. The spirit of diversity must continue to exist in the nation's children, this also shows the fact that humans cannot choose which group they should be born from.

Cooperative learning usually begins with the formation of small groups of 4-5 students. The basis for forming groups is heterogeneous. The basis for showing heterogeneity, teachers generally use the child's pretest scores or test basic competencies beforehand. The use of values as a basis for forming these groups for less competent children will make inferiority. This inferiority complex will make a child who is lazy to learn. If this happens, the teacher's burden increases (Moleong, J. L., 2010).

Teaching and learning techniques of cooperative learning informing teacher groups create heterogeneous groups by paying attention to academic abilities (Isjoni, 2011: 95). Heterogeneous in terms of ability, sex, and ethnic background (Slavis, 2005: 11).

Heterogeneous can be formed by paying attention to gender diversity, religious background, socio-economic, and ethnic as well as academic abilities (Lie 2008: 41). Lie further suggested that group members could be made permanent or non-permanent. The disadvantage is that if the permanent group has less interaction between students, the non-permanent group is not time efficient. Non-permanent groups are recommended by appointment hours. 
If groups are changed frequently, students will have more opportunities to interact with other students. An efficient way is suggested which is to use appointment hours. This agreement hour applies the change of members every hour. (Lie 2008: 44). For this suggestion, students can spend too much time, especially if the hours in the subject are only two hours, so that the time runs out is only for transfer activities between members of the group.

To prevent this, the change of group members is not based on the hour of the agreement but based on the session agreement or every face-to-face meeting. If the subject matter has not been completed and if changing members will make it difficult for students, the previous membership can still be maintained. Heterogeneity based on group formation will be more efficient is based on student seating and systematically calculated. Students sit in elementary to high school, students who choose and are determined by the teacher/homeroom teacher, so students do not sit to move. This determination makes it easier for teachers to manage classrooms classically, but subject teachers have the authority to organize classes in their subjects (Moleong, J. L., 2010).

Submission of group formation can be delivered at the beginning of the semester learning. A list of group members in each subject can be posted on the class notice board. It is hoped that in the next session/meeting students will already know who the group members are. With effective learning planning, it is expected to get optimal learning results. Technically the basis for forming heterogeneous groups can be started by counting the number of children in the class, then dividing the desired groups, for example, 5 groups. Children count to the count of the number of groups $(1,2,3,4,5)$ and then starting from number 1 and the same number joined into one.

The initial calculation can be started from the front and left seats in a spiral until the count in the class runs out, the formation of the first group. Formation of groups in subsequent sessions/meetings counting can start from where students sit right to left, the next session using oblique and continues to be varied so that children in one semester the possibility of interacting in one group is rare/small. If all subject teachers refract in using a variety of ways without showing the class of student competencies, it will encourage those with low competency to learn better. Appreciation and togetherness between students will increase because equality and fairness between them are the same. Cultivation in forming this group will form a positive school culture (Olson, L.M., (2020).

Meaning from the basis of forming this group in addition to Multicultural Education which shows that humans in life/work outside of their families are not always what we want them to be. For this, we need to adapt to anyone, anywhere and can work with anyone 
with a different background (Olson, L.M., (2020).

\section{DISCUSSION}

a. Multicultural Indonesia

Multicultural Education in Indonesia can build the nation going forward, efforts are needed to implement the principles of the multiculturalism movement to be the nation's goal in a plural society. Amirin, (2012) emphasized that in multicultural societies such as Indonesia, a paradigm of dialogue or mutual understanding is needed, to overcome the negative excesses of the problem of national disintegration. Before continuing, in the context of its implementation in Indonesia, multicultural, education can be seen or positioned as follows: 1) As an educational philosophy; namely the view that Indonesia's rich cultural diversity must be utilized as well as possible to develop and improve the education system and teaching and learning activities in Indonesia to achieve a just and prosperous (blessed) and happy Indonesian society in the hereafter. 2) As an educational approach; namely the implementation and implementation of contextual education, which takes into account Indonesia's cultural diversity. 3) Field of study and field of study; that is, scientific disciplines - assisted by sociology and anthropology of education, examining culture, especially cultural values and their manifestations (norms, etiquette or beaviuor, customs or traditions, etc.) including "cultural manifestations" of religion) for administration and education implementation (Olson, L.M., 2020).

Multicultural education that develops in Indonesia is considered to be in conflict with the policy of decentralization and regional autonomy, because multicultural education in Indonesia is relatively new. To realize this, multicultural education in Indonesia needs to use a combination of existing models, so as proposed by Gorski (in Mahfud, 2009), which includes three types of transformation, namely: (1) selftransformation; (2) school transformation and teaching and learning process, and (3) community transformation. The multicultural education model is not a formality that merely revises learning materials but more broadly than that, multicultural education is demanded to be able to reform the learning system itself (Olson, L.M., (2020).

Transformation activities itself, multicultural education have able to direct students to be able to change their mindset of a narrow ethnocentrism view into a multicultural view as a necessity that is a gift of God. In school transformation, activities in teaching and learning processes, multicultural education must be a top priority in building togetherness among differences (Tyler, R.W., 1949).

The teacher is a facilitator required to be able to direct students into forms of learning that allow for harmonious dialogical relations in responding to differences in culture, religion, and culture. In the community, 
transformation activities, a community order must create that prioritizes a harmonious and balanced interaction in dealing with differences. The community must merge into a cosmopolitan society that no longer sees the dominance of one group over another, antipathy in interacting with other groups and mutual respect for differences in the social structure of society.

Multicultural teaching strategies must develop a curriculum that can integrate the process of learning values, knowledge and "life" skills in a multicultural society, such as implementing cooperative learning, and problem-solving, in order to improve the internalization of Indonesian cultural values in the lives of students in their communities. Secondly, teachers have a concern for their students, so that multicultural education can be realized in Indonesia. Multicultural education in Indonesia, according to Kusmaryani (without years), there are four main points, among others: First, the multicultural education curriculum model in Indonesia reflects the values of the Indonesian nation's culture (Efendi \& Lien, 2020). Teachers implementing multicultural education learning must be "flexible" because, in multicultural education learning such as in Indonesia, there are "cultural differences" that are important points that should be a teacher's attention (Tyler, R.W., 1949).

Building multicultural education strategies are respecting the diversity of ethnicities, religions, languages, and cultures are: 1 ) teachers can build a critical understanding, and develop of differences among students live together in social status, building ethnicity and anti-discrimination must be done. 2) Students are packaged in the realm of learning and awareness in school, so students as to be able to create understanding to understand and accept differences that exist in each individual student and ultimately students are expected to have a strong character to always be democratic, pluralist and humanist. 3) The learning process developed must place students in the surrounding social reality. A learning process that relies on students to learn in groups and compete in groups in positive competitive situations. Differences between individuals can be developed as a group strength and students are accustomed to living with various cultural, social, economic, intellectual and political aspirations (Wheeler, D. K., 1967). In this way, differences between individuals can be developed as a group force and students are accustomed to living with various cultural, social, economic, intellectual and political aspirations. 4) Performance appraisal, portfolio assessment, rubric assessment, observation guidelines, interview guidelines, rating scale, attitude scale, checklist, and questionnaire are assessment tools that can be used to evaluate learning using a multicultural approach, the evaluation used must cover all aspects of abilities and student personality with the goals and content developed (Wheeler, D. K., 1967). 


\section{b. The curriculum design of Multicultural Cooperative Learning}

Besed on Permendikbud number 103 of 2014 concerning Learning in Primary and Secondary Education that the learning plan at least contains: (a) school identity, subject or theme, class/semester, and time allocation; (b) Core Competencies, Basic Competencies and indicators of achievement of competencies; (c) learning material; (d) learning activities that include preliminary activities, main activities, and post activities; (e) valuation, enrichment; and (f) media, tools, materials and learning resources. In Implementing Cooperative Learning in Multicultural Education Developing Character, Nationalism and Case Studies of Religion in MIN 3 Grobogan, Central Java Indonesia in the dimension of teacher planning must have a good attention to the development of student learning.

Multicultural teaching strategies, the teacher implements a plan of learning activities in the classroom so that it has the characteristics as mentioned in Permendikbud number 103 of 2014, the teacher builds interactive and inspirational; students who are fun, challenging, and motivate students to actively participate; contextual and collaborative; provide sufficient space for student innovation, creativity, and independence; and in accordance with the talents, interests, abilities, and physical and psychological development of students.
The main point in interactive activities, success in multicultural teaching strategies is the teacher allows students to interact during the learning process, and the learning also inspires students, so it can be said to be successful because the teacher teaches with a polite appearance, good attitude and clear. Roles in the teaching and learning process, the teacher honors and appreciates each student, and the teacher also accustoms discipline, comfort, and pleasure during the teaching, and learning process. However, we have to make lesson plans, some methods used to the meeting of one topic and learning, and it does use ICT. So, the previous meeting activity did not only task, so that made the classroom atmosphere not boring and alive. Teachers must develop teaching, and learning process that is fun and challenging can occur when there is a game or performance of work in front of the class, different things happen to learn that motivates students to actively participate and teachers are familiar with the use of ICT, so the teacher when taking student scores, with authentic learning. these efforts are proven to make students active and students realize that it is their own needs from the consequences of the score.

\section{CONCLUSION}

Education in Indonesia, whose society consists of various races, ethnic groups, nationalities, and religions, considered important for implementing multicultural education. Because it cannot be denied 
that with this diverse Indonesian society, it is often the cause of various kinds of conflict.

Multicultural based on education applied a strategic learning role in being able to achieve pluralism productively, in Indonesia, which is known for its diverse ethnic, religious and national cultures, so that multicultural education can be socially transformed and reform can be managed intelligently and become part of the enlightenment of national life in the future so that it can overcome conflicts that occur into a nation that can live together and respect each other in the life of the nation and state in Indonesia.

Multicultural education in Indonesia can only be developed through continuous and integrated efforts. Role and support from teachers/teaching staff, educational institutions, and other educational policymakers, especially in applying the curriculum with a multicultural approach.

Teachers and educational institutions (schools) need to understand the concept of multicultural education from a global perspective so the values contained in this education able to teach as well as practice in front of the students. Through the development of this multicultural education, the students will more easily understand the lessons and increase their awareness always to behave humanist, pluralist and democratic.

\section{IMPLICATION OF THE STUDY a. The Significance of Research}

What differences this research from previous research, the author emphasizes more on the government and teachers in the application of the education curriculum, so that it can be a means of unifying nation's educational strategies, having ethnic, religious and ethnic differences so that students can absorb and implement the Implementation of Cooperative Learning in Multicultural Education, Develop Character, Nationalism and The Case Study of Religion in MIN 3 Grobogan, Central Java, Indonesia.

Understanding the shared awareness of the Government, teachers, and the community the importance of multicultural education applied to the elementary school curriculum. However, its implementation and practice are very complicated because of the important and challenging issues mentioned in Education in Indonesia, whose community consists of various races, ethnic groups, nationalities, and religion, are considered important for implementing multicultural education. Because it cannot be denied that with this diverse Indonesian society, it is often the cause of various types of conflicts. In the context of Indonesia, which is known for its content that is full of diversity, the role of multicultural-based education becomes strategic can be managed by increasing curriculum innovation, the professionalization of teachers, increasing the quality of ICT. so that an intelligent generation is realized and becomes part of the enlightenment of national life going forward. Multicultural 
education in Indonesia can only be developed through continuous and integrated efforts. The role and support of teachers/teaching staff, educational institutions, and other educational policy makers, especially in implementing the curriculum with a multicultural approach. Teachers and educational institutions (schools) need to understand the concept of multicultural education from a global perspective so that the values contained in this education are able to teach and also practice in front of students. Through the development of this multicultural education, students will more easily understand the lessons and increase their awareness to always behave humanist, pluralist and democratic.

\section{b. Finding of research}

This study shows the extent to which the Implementation of Multicultural Education Cooperative Learning Develops Character, Nationalism and Case Studies of Religion in MIN 3 Grobogan, Central Java Indonesia, the application of the 2013 curriculum can affect the learning activities delivered by teachers. In terms of overcoming the Implementation of the Multicultural Cooperative Learning Elementary School in MIN 3 Grobogan, in delivering the magnitude of the influence of the efforts made by the teachers. As a benchmark for the success of the 2013 Curriculum, the role of an evaluation carried out effects overcoming obstacles and achieving student learning outcomes in the application of the 2013 Curriculum. From the explanation above, some conclusions are as follows: 1) Awareness about cultural diversity. Multicultural education can be used as a strategic instrument to develop awareness of one's pride towards ethnic groups that can be taught with the Multicultural Teaching Strategies approach in schools. 2) Compounding societies such as the Indonesian state, which have ethnic, religious, linguistic and cultural differences, urgently need new constructs that are just, equitable, and democratic societies, very compatible with multicultural education strategies, so that they grow in tolerance and mutual respect between ethnic groups. 3) The application of multicultural education in an integrated or integrated curriculum with other subjects. 4) The application of integrated multicultural education can use cooperative learning models. 5) The basis for efficient group formation is the formation of nonpermanent groups with session agreements or face-to-face meetings, which allow students to interact in turns with classmates. 6) Socialization on the basis of the formation of various groups in the cooperative learning model will develop an awareness that life now and later for students has no problem in adjustment.

\section{ACKNOWLEDGMENT}

We would like to thank the principal, the vice principal of the curriculum and all the MIN 3 Grobogan teachers, who have participated, provided support and advice to us so that we got a lot of information about my research. Hopefully, this 
research can be useful for us all. Thank you very much.

\section{REFERENCES}

Amirin, T., M. (2012). Implementation of the Contextual Multicultural Education Approach Based on Local Wisdom in Indonesia. Journal of Development and Education, 1(1).

Azra, A. (2007). Cultural Identity and Crisis: Building Indonesian Multiculturalism. http://www.kongresbud.budpar.go .id/58\%20ayyumardi\%20azra.htm

Banks, J., A. (2002). An Introduction to Multicultural Education. Boston: Allyn and Bacon. Canadian multiculturalism act. 1988 in Library and Archives Canada. Statutes of Canada. An Act for the Preservation and Enhancement of Multiculturalism in Canada, 1988, SC 36-37 Elizabeth II, Volume I, Chapter 31

Banks, J., A. (2002). An Introduction to Multicultural Education. Boston: Allyn Bacon.

Banks, J. A. (2007). Educating Citizens in a Multicultural Society. New York: Teacher College.

Banks, J. A. (1987). Teaching Strategies for Ethnic Studies, 4 ed. Boston: Allyb and Bacon.

Cordasco, F. (1976). A brief history of education: a handbook of information on Greek Roman, medieval, Renaissance and modern educational practice, $2^{\text {nd }}$
Ed. Lahjam, MD: Rowan \& Littlefield.

Deviani, H. (2013). The Dynamics of Canadian Multiculturalism (19682006).

htttp://heidistoria.blogspot.com. Online accessed on 15 September 2013.

Efendi, M. Y., \& Lien, H. N. (2020). The Comparison of Elementary Curriculum Education between Indonesia and Singapore. Journal of Teaching and Learning in Elementary Education, 3 (1), 2236.

Gardner, H., Csikszentmihalyi. M., \& Damon, W. (2009). Good work: when excellence and ethics meet. New York, NY: Basic Book.

Geertz, C. (1973). The Interpretation of Cultures.New York: Basic Books.

Glare. P. G. W. (2000). Oxford Latin dictionary. Oxford: Oxford University Press.

Grahama. G. (2004). Eight theories of ethics. New York, NY: Routledge.

Isjoni, I. (2011). Cooperative Learning: Improving Communication Intelligence among Students. Yogyakarta: Pustaka Pelajar

Kamanto, S. (2004). Multicultural Education in Indonesia and South Asia: Stepping into the Unfimiliar. Jurnal Antropologi Indonesia. Departemen Antropologi: Fakultas Sosial Politik UI.

Kusmaryani, Y. (No Year). Multicultural Education; A Study of Alternative Education in Indonesia to ReAdherence the Values of Unity, 
Unity and Nationality in the Global Era. Online (12 September 2013)

Lie, A. (2008). Cooperative Learning: practicing Cooperative Learning in Classrooms. Jakarta: Grasindo.

Mahfud, C. (2009). Multicultural Education. Yogyakarta: Pustaka

Moleong, J. L. (2010). Metodologi Penelitian Kualitatif ( $A$ method of qualitative research). Bandung, IND: Remaja Rosda Karya.

Noel, J. (2000). Multicultural Education. Dushkin: on-line

Olson, L. M. (2020). The relationship between moral integrity, psychological well-being and anxiety. Retrieved from www.char

Parekh, B. (2000). Rethinking Multivulturalism: Cultural Diversity and Political Theory. Cambridge: Havard University Press

Pelajar, R. N. (2005). Building an Empowering and Enlightening Education. Jakarta: Grafindo

Phierquin, P. (2013). Comparison of Multiculturalism in Various Countries.

http://phierda.wordpress.com/ Online (diakses 15 September 2013).

Piaget, J. (1962). Play, dreams and imitation in childhood, W. W. Norton \& Company, New York.

Rodriguez, H. (2006). The playful and the serious: An approximation to Huizinga's Homo Ludens. The International Journal of Computer Game Research, 6(1). Retrieved on $9 / 5 / 2020$ from http://gamestudies.org/0601/articl es/rodriges

Seligman, M. E. P. (2002). Authentic happiness: Using the new positive psychology to realize your potential for lasting fulfillment. Free Press, New York.

Seligman, M. E. P. (2011). Flourish: A new understanding of happiness and well-being - and how to achieve them. Nicholas Brealey Publishing, London.

Shamad, I. (2009). Ethnic Politics and Culture: Australian Version of Multiculturalism. http://irhashshamad.blogspot.com / Online (diakses 15 September 2013)

Shipley, D. (2008). Empowering children. Play based curriculum for lifelong learning. (Fourth edn). Nelson Education, Toronto.

Singh, S. (2014). Creating a joyful learning environment at primary level. Shaikshik Parisamvad (An International Journal of Education) 4(1), 10-14.

Slavin, R., E. (2005). Cooperative Learning: Theory, Research and Practice. Bandung: Nusa Media.

Sudardi, B. (2003). Penggarapan Naskah. Surakarta: Badan Penerbit Sastra. Indonesia.

Sukmadinata, N. S. (2008). Pengembangan Kurikulum: Teori dan Praktek. Remaja Rosdakarya : Bandung.

Suparlan, P. (2002). Citizens' Equality and Community Cultural Rights in Indonesian
Compound 
Communities. Jurnal Antropologi Indonesia. Vol 6 (1-12)

Sutton-Smith, B. (1997). The Ambiguity of Play, Harvard University Press, Cambridge, MA.

Thanos, P. K., Katana, J. M., Ashby, C. R., Michaeldes, M., Gardner, E. L., Heidbreder, C. A. (1999). The selective dopamine D3 receptor antagonist SB-277011-A attenuates ethanol consumption in ethanol preferring $(P)$ and nonpreferring (NP) rats.

Pharmacology, Biochemistry and Behavior, 81(1), 190-197.

Tilaar, H. (2005). National Education Manifesto: An Overview from a Perspective of Postmodernism and Cultural Studies. Jakarta: Kompas ---------- 2004. Manajemen Pendidikan Nasional, Bandung: P.T Remaja Rosdakarya

Tyler, R. W. (1949). Basic principles of curriculum and instruction. Chicago: University of Chicago Press.

Vygotsky, L. S. (1962). Thought and Language, Wiley, New York.

Waterworth, P. G., Segrave, S. \& Warren, C. (2001). 'New pedagogies: using constructivist insights in developing online studies in education'. In Lertchalolarn, C. et al (Eds), Reforming Teacher Education for the New Millennium: Searching for New Dimensions. Proceedings of the International Conference, Chulalongkorn University in association with
SEAMEO RIHED, Bangkok, July 2000.

Waterworth, P., \& Duangpaeng, A. (2004) 'Contexts in cooperative learning: using cooperative learning strategies in teacher education in Australia and Thailand'. Paper presented at the International Association for the Study of Cooperation in Education - National Institute of Education Conference, Singapore, June.

Wheeler, D. K. (1967). Curriculum process. London: University of London Press.

Willis, J. (2007). The Neuroscience of Joyful Education. Engaging the Whole Child, 64, summer. Retrieved on $9 / 5 / 2020$ from http://www.ascd.org/publications/ educationalleadership/summer07/vol64/num0 9/The-Neuroscience-of-JoyfulEducation.aspx

Zamroni, Z. (2008). Multicultural Education: Philosophy, Policy and practice vol. 1 A Reader. Yogyakarta: Graduate Program the State University of Yogyakarta.

Zamroni, Z. (2011). Democracy Education in Multicultural Communities. Yogyakarta: Gavin Kalam Utama. 